•综述・

\title{
陆地生态系统中马陆的生态功能
}

\author{
王梦茹 傅声雷 徐海翔 王美娜 时雷雷
}

(河南大学环境与规划学院, 河南开封 475004)

\begin{abstract}
摘要: 马陆是陆地生态系统中物种多样性极高的大型土壤无脊椎动物类群。作为营腐生动物, 马陆在陆地生态系 统中具有不可替代的重要功能。通过大量取食及随后的肠道过程, 马陆在很大程度上决定着陆地生态系统调落物 的破碎、转化和分解过程, 从而驱动碳和关键养分元素的循环周转。然而, 目前对马陆生态功能的研究还非常有 限, 远远落后于其他土壤动物类群(如虾蚂等)。本文初步总结了马陆的生态功能: (1)通过破碎、取食调落物来加速 调落物的分解。马陆偏好取食半分解的调落物, 其同化效率受到调落物来源、温度和调落物中微生物含量的影响。 (2)主要通过取食和排泄等活动影响养分循环。但对于马陆如何影响土壤碳循环, 存在两种不同的观点: 一是马陆 粪球的分解速率比调落物更快, 加速了碳的循环; 二是马陆粪球更难分解, 有助于碳的固存和稳定。马陆破碎调落 物后, 调落物释放氮素进入土壤。此外, 马陆的活动也影响土壤磷的循环, 提高土壤中有效磷的含量。(3)调控微 生物特性, 与虾蚓也有互作关系。通过以上三个方面的总结, 展望了未来马陆的主要研究方向, 以期引起更多思考 和研究。
\end{abstract}

关键词：马陆; 土壤动物; 陆地生态系统; 生态功能

\section{Ecological functions of millipedes in the terrestrial ecosystem}

\author{
Mengru Wang, Shenglei Fu, Haixiang Xu, Meina Wang, Leilei Shi* \\ College of Environment and Planning, Henan University, Kaifeng, Henan 475004
}

\begin{abstract}
Millipedes (Diplopoda) are a highly diverse group of soil invertebrates and play vital roles in terrestrial ecosystems. Millipedes contribute to the cycling of carbon and nutrients through their feeding activities and gut processes that help decompose litter. However, the functions of millipedes have been poorly researched compared to other groups of soil animals such as earthworms. Here, we briefly summarize the ecological functions of millipedes: Millipedes can fragment, consume and transform litter to accelerate its decomposition. Millipedes prefer large amounts of semi-decomposed litter and the efficiency of millipedes in assimilating litter can vary with litter source, temperature and microbial biomass in the litter. Millipedes can regulate the cycling of soil carbon and other key nutrients through feeding and excretion activities. Nitrogen enters to the soil when litter is fragmented by millipedes, but there are different views on how millipedes affect the soil carbon cycle. Millipede faeces decompose more rapidly than the pre-ingested litter. Such a transformation of litters to faeces would accelerate carbon cycling. However, other studies have suggested a relatively low decomposition rate of millipede faeces when compared with un-ingested litter, which could contribute to soil carbon sequestration and stabilization. In addition, the survival of millipedes affects soil phosphorus cycle. They can increase the content of available phosphorus in soil. Millipedes interact with other soil animals such as earthworms and also can regulate the abundances of soil microorganisms. Our review indicates that further studies are required to better understand and document the role of millipedes in ecosystem functioning.
\end{abstract}

Key words: millipede; soil fauna; terrestrial ecosystem; ecological functions

收稿日期: 2018-03-26; 接受日期: 2018-07-17

* 通讯作者 Author for correspondence. E-mail: shileilei1985@163.com 
马陆俗称 “千足虫”, 是节肢动物门多足类倍足 纲(Dipolopoda)动物的统称。马陆是节肢动物门继昆 虫纲和蛛形纲之后物种多样性最丰富的无脊椎动 物类群(Shelley, 2003)。目前已经报道的马陆有 12,000 多个物种, 分属 16 目 147 科 1,868 属 (Adis, 2002; Shelley, 2003; Sierwald \& Bond, 2007)。马陆在 陆地生态系统中的分布非常广泛, 在森林、草地、 农田以及城镇绿地和居民区皆可发现, 并且数量丰 富(Hopkin \& Read, 1992; Hashimoto et al, 2004)。然 而, 目前人们对马陆的研究非常有限, 国内更是鲜 有报道(张雪萍等, 2001; Marek \& Bond, 2006), 国 际上目前仅对几种常见马陆, 如欧洲球马陆 (Glomeris marginata)的生物学和生态学有一定的研 究(Anderson \& Bignell, 1980; Marek \& Bond, 2006; Rawlins et al, 2006)。

自20世纪50年代以来, 作为土壤动物的重要类 群, 马陆的生态功能逐渐受到生态学家的关注。作 为营腐生的大型土壤动物, 马陆喜欢阴暗潮湿的环 境, 主要生活在陆地土壤和调落物层(Drift, 1975)。 大部分马陆主要以调落物为食, 通过取食和随后的 肠道过程, 把调落物破碎转化为粪球, 从而加速了 调落物的分解、周转以及土壤表层腐殖质的形成, 在土壤关键元素的循环、土壤结构形成以及健康维 持方面起着不可替代的重要作用(Shelley, 2003)。因 此, 马陆被称为陆地生态系统中的模式分解者, 是 土壤食物网不可或缺的组成部分, 也是生态系统能 量流动和物质循环周转的重要驱动者。由于马陆物 种的多样性和复杂性, 科学界对它们的研究目前还 主要停留在分类描述方面, 只有少数学者关注马陆 的生态功能, 并且在研究的深度和广度方面远远不 及其他土壤动物类群 (如虹蚓、线虫和跳虫等) (Coleman \& Crossley, 1996; Shelley, 2003; Ashwini \& Sridhar, 2005)。

随着当今国内外科学界对土壤生物学的重视, 以及从地上和地下互作的角度来研究生态系统的 结构和功能(Wang et al, 2017), 马陆作为陆地生态 系统中的分解者和养分周转的调控者, 被越来越多 的研究者关注。同时, 考虑到马陆的多样性以及分 布的广泛性, 有必要加强对马陆生态功能的深入研 究。鉴于此, 本文基于国内外现有的有限文献, 初 步总结了当前对马陆生态功能的认识(图1)。主要关 注马陆在生态系统中的 3 个关键功能: (1)在调落物
破碎、转化和分解方面的作用; (2)对土壤碳和关键 养分元素生物地球化学循环的调控作用; (3)与其他 土壤生物的互作关系。拟通过这些总结，展望未来 马陆的研究方向, 以期引起更多思考和研究。

\section{马陆在凋落物破碎、转化和分解方面的作}

邵元虎等(2015)认为, 土壤动物的生态功能主 要通过取食作用和非取食作用来实现。马陆作为大 型土壤动物之一, 其丰富度较高, 在森林生态系统 中除了可以破碎分解调落物外，还能通过自身活动 影响土壤结构、养分循环和植物生长发育。马陆在 生态系统中被认为是调落物转换者, 对调落物的分 解分为直接作用和间接作用两个方面 (Lavelle \& Spain, 2001)。直接作用指马陆取食消耗调落物。与 新鲜调落物相比，马陆更偏好取食半分解的调落 物。原因包括: 第一，马陆体内缺乏分解酶，而新鲜 调落物中富含的单宁和多酚不易被马陆消化。半分 解的调落物中酚类物质的含量较低, 糖类物质的含 量较高, 且其中的酚类物质通过淋溶作用和微生物 代谢被去除，易被马陆同化吸收(Sakwa, 1974; Devi \& Prabhoo, 1990; Ashwini \& Sridhar, 2005)。第二, 半分解的调落物通常会被微生物定殖, 马陆取食这 类调落物，能够通过消化大量的真菌增加对钙的吸 收，这对于马陆完成生活史十分重要(Lyford，1943; Reichle et al, 1969)。间接作用表现为马陆通过破碎 调落物，增大调落物与微生物接触的表面积，同时 加速了其他土壤动物对调落物的分解(Kheirallah, 1990; Bonkowski et al, 1998)。此外，马陆将部分未 完全消化的调落物残质转化为粪球后, 微生物继续 进行分解 (Tajovský et al，1992; Wolters，2000; Bardgett \& Wardle, 2010)。马陆的这些特点使其在调 落物分解方面所起的作用与其他大型土壤动物有 明显的区别。比如与蚯蚓相比，马陆主要通过肠道 过程把调落物转化为粪球, 改变调落物的形态, 而 蚯蚓主要把调落物与土壤混合, 深栖类蝐蚓能将调 落物拖入洞穴, 改变了调落物所处的位置(Edwards \& Hendrix，2004; 张卫信等，2007; Bardgett \& Wardle, 2010)。

马陆对调落物的消耗率较高, 同化率较低。在 不列颠哥伦比亚大学马尔科姆·纳普森林中, 带马 陆目的物种Harpaphe haydeniana, 每天消耗的调落 


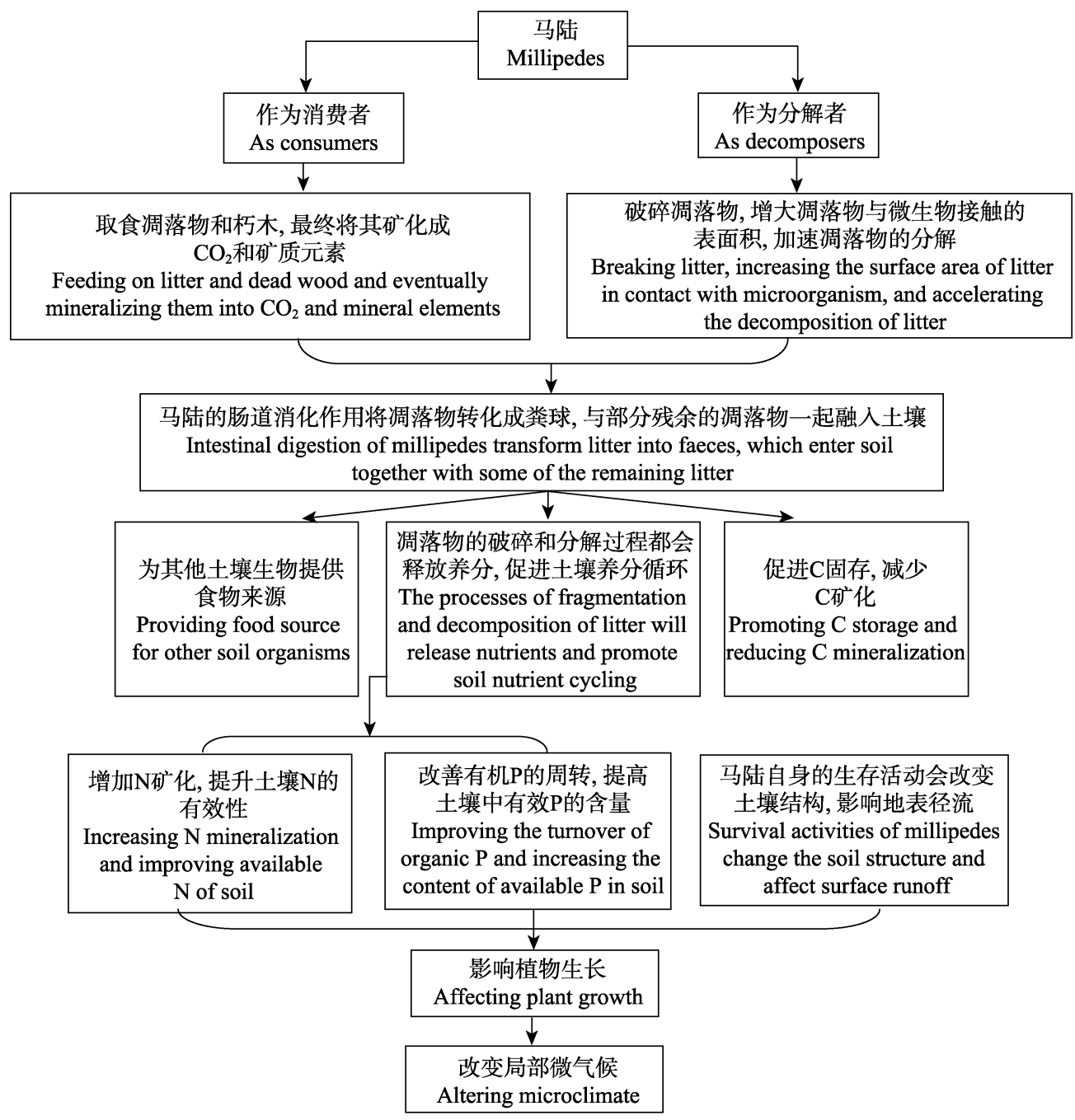

图1 马陆的生态功能

Fig. 1 Ecological functions of millipedes

物是其自身生物量的10-20\%。在不列颠哥伦比亚省 沿海温带森林, 每年调落物输入量的36\%被马陆所 消耗, 但是其同化率低于 $10 \%$ (Cárcamo et al, 2000)。也有研究发现马陆每年约可以消耗温带森林 里 10-15\%的调落物 (Golovatch \& Kime, 2009)。 David 和Gillon (2002)认为, 马陆对调落物的消耗 率和同化率受马陆物种、体型大小、雌雄状况、季 节变化及调落物分解程度的影响。随着马陆体型的 增长, 其消耗率和同化率也增加。成虫阶段的雌性 马陆的体型和重量大于雄性马陆, 因而两者消耗率 和同化率也有差异。一年中, 春季时马陆对调落物 的消耗率与同化率较高, 且对分解程度高的调落物 的同化率高于分解程度低的调落物。马陆在摄食时 又会表现出取食偏好 (Barlow, 1957; Ashwini \& Sridhar, 2005; Buch et al, 2018), 其所偏好的调落物
与凋落物的化学性质相关(Sakwa，1974)。Ashwini 和Sridhar (2005)通过设置不同植物调落物研究了 Arthrosphaera magna对调落物的取食, 发现在大叶 相思(Acacia auriculiformis)、槟榔(Areca catechu)、 香蕉(Musa nana)、腰果(Anacardium occidentale)和 椰子 (Cocos nucifera) 5 种植物中, Arthrosphaera $m a g n a$ 最偏好槟榔调落物, 其次为香蕉、大叶相思、 腰果和椰子调落物。由于马陆体内缺少酚氧化酶, 不易消化酚类含量较高的调落物(张雪萍等, 2001; Ashwini \& Sridhar, 2005), 且其生长需要摄入大量 的钙(Lyford, 1943; Reichle et al, 1969), 而槟榔、香 蕉等凋落物中的总酚含量比另外 3 种植物低, 钻含量 相对较高, 适宜马陆生长。

有关马陆同化效率研究的结果差异较大(表1)。 Drift (1975)测得Glomeris marginata对夏栎(Quercus 
表1 马陆的同化效率

Table 1 Assimilation efficiency of millipedes

\begin{tabular}{|c|c|c|c|c|c|c|c|}
\hline $\begin{array}{l}\text { 目 } \\
\text { Order }\end{array}$ & $\begin{array}{l}\text { 科 } \\
\text { Family }\end{array}$ & $\begin{array}{l}\text { 属 } \\
\text { Genus }\end{array}$ & $\begin{array}{l}\text { 种 } \\
\text { Species }\end{array}$ & $\begin{array}{l}\text { 生存地点 } \\
\text { Locality }\end{array}$ & $\begin{array}{l}\text { 调落物 } \\
\text { Litters }\end{array}$ & $\begin{array}{l}\text { 同化效率 } \\
\text { Assimilation } \\
\text { efficiency (\%) }\end{array}$ & $\begin{array}{l}\text { 参考文献 } \\
\text { References }\end{array}$ \\
\hline $\begin{array}{l}\text { 球马陆目 } \\
\text { Glomerida }\end{array}$ & Glomeridae & Glomeris & G. marginata & $\begin{array}{l}\text { 荷兰棌树林 } \\
\text { Oak forests in the Netherlands }\end{array}$ & 夏栋 Quercus robur & $9 \%$ & \\
\hline $\begin{array}{l}\text { 球马陆目 } \\
\text { Glomerida }\end{array}$ & Glomeridae & Glomeris & G. marginata & $\begin{array}{l}\text { 法国南部蒙彼利埃西北 } \\
25 \text { km的冬青栎森林 } \\
\text { Q. ilex forest of Puechabon, } 25 \\
\text { km north-west of Montpellier } \\
\text { (southern France) }\end{array}$ & 冬青栎 Quercus ilex & $6 \%$ & $\begin{array}{l}\text { David \& } \\
\text { Gillon, } 2002\end{array}$ \\
\hline $\begin{array}{l}\text { 带马陆目 } \\
\text { Polydesmida }\end{array}$ & Xystodesmidae & Harpaphe & H.haydeniana & $\begin{array}{l}\text { 加拿大马尔科姆·纳普研究森林 } \\
\text {-— } \\
\text { 温哥华不列颠哥伦比亚大 } \\
\text { 学校园附近的成熟混合林 } \\
\text { Malcolm Knapp Research } \\
\text { Forest, near the University } \\
\text { of British Columbia campus } \\
\text { in Vancouver }\end{array}$ & $\begin{array}{l}\text { 北美乔柏 Thuja plicata } \\
\text { 西加云杉 Picea sitchensis } \\
\text { 异叶铁杉 } \\
\text { Tsuga heterophylla } \\
\text { 花旗松 } \\
\text { Pseudotsuga menziesii }\end{array}$ & $10 \%$ & $\begin{array}{l}\text { Cárcamo et } \\
\text { al, } 2000\end{array}$ \\
\hline $\begin{array}{l}\text { 异蛩目 } \\
\text { Spirostreptida }\end{array}$ & Spirostreptidae & Orthoporus & O. ornatus & $\begin{array}{l}\text { 美国德克萨斯州大弯国家公园 } \\
\text { Big Bend National Park, Texas, } \\
\text { USA }\end{array}$ & $\begin{array}{l}\text { 麻黄属 Ephedra } \\
\text { 蜂蜜牧豆树 } \\
\text { Prosopis glandulosa }\end{array}$ & $20-37 \%$ & $\begin{array}{l}\text { Wooten \& } \\
\text { Crawford, } \\
1975\end{array}$ \\
\hline $\begin{array}{l}\text { 山望目 } \\
\text { Spirobolida }\end{array}$ & Pachybolidae & Trigoniulus & T. lumbricinus & 古巴 Cuba & $\begin{array}{l}\text { 咖啡属 Coffea } \\
\text { 木槿 Hibiscus } \\
\text { 棣属 Panicum }\end{array}$ & $55 \%$ & $\begin{array}{l}\text { Pobozsny et } \\
\text { al, } 1992\end{array}$ \\
\hline
\end{tabular}

robur) 调落物的同化效率为 $9 \%$, David 和 Gillon (2002)发现G. marginata对冬青柇(Q. ilex)调落物的 同化效率为6\%, Cárcamo等(2000)研究表明, 基于调 落物的干质量计算, 马陆对调落物的同化效率约为 $10 \%$, 较低的同化效率致使马陆需通过大量取食来 满足营养需求。而Wooten和Crawford (1975)测定 Orthoporus ornatus的同化效率为 20-37\%, 且具有 温度依赖性, 会随着温度的升高而增加。Pobovsny 等(1992)发现Trigonoiulus lumbricinus的同化效率高 达 $55 \%$ 。马陆同化效率的高低可能受到食物来源和 温度的影响。易同化的营养物质, 如糖和蛋白质, 其浓度越高, 同化效率越高。微生物组织很容易被 马陆同化, 同化效率可达70-90\%。所以当调落物中 微生物的生物量增大时, 马陆的同化效率也随之增 加 (Crawford, 1975; Bailey, 1989; Byzov et al, 1998a)。可见, 当食物来源、温度、调落物的分解 程度或调落物上微生物定殖状况不同时, 马陆的同 化效率就会不同。

\section{2 马陆对土壤碳和关键美分元素生物地化挀 调控作用}

\section{1 马陆对土壤碳循环的影响}

马陆取食调落物后, 通过肠道消化吸收及大量
粪球的排泄而影响碳的循环过程(Scheu \& Wolters, 1991; Cárcamo et al, 2000; Makoto et al, 2014)。目前 关于马陆如何影响土壤碳循环存在两种截然不同 的观点。传统的观点认为, 马陆破碎调落物, 将其 转化为粪球, 增加了调落物的比表面积, 同时粪球 能激发微生物活性, 从而加速碳的矿化过程(Scheu \& Wolters, 1991)。而最近10年来的研究发现马陆把 调落物转化为粪球后并未加速碳的矿化过程, 反而 促进了土壤碳的稳定性。Rawlins等(2006)研究了球 马陆(Glomeris narginata)把调落物转化为粪球后调 落物化学成分的变化以及对土壤碳的影响, 发现调 落物中的可溶性部分被马陆吸收, 留下了难分解的 木质素等物质, 使粪球更难分解, 从而促进了土壤 碳的稳定性。随后Suzuki等(2013)在加拿大海岸森 林研究了带马陆(Harpaphe haydeniana) 粪球和调落 物分解速率的差异, 发现粪球的分解速率比调落物 更慢。同样, Frouz等(2014)的研究也发现，马陆将调 落物转化为粪球, 促进了土壤中的碳固存, 减少了 碳矿化。马陆促进土壤碳稳定性和累积的过程还与 其食性密切相关, 比如日本列车马陆(Parafontaria laminata) 在成虫阶段取食土壤和调落物的混合物, 产生的粪球能够把调落物包裹起来, 从而增加土壤 层中的碳积累, 尤其是在马陆密度较高的情况下效 
果更显著(Toyota et al, 2006)。

马陆对土壤碳循环和稳定性的影响受到它们 所取食调落物的性质以及气候、土壤等因素的作用, 是一个很复杂的过程。但是最近的研究都表明马陆 在土壤碳稳定性方面起着重要的作用。在全球变化 导致 $\mathrm{CO}_{2}$ 排放增加的背景下, 充分理解马陆在土壤 碳稳定性方面的作用对促进陆地生态系统碳固存 意义深远。

\section{2 马陆对土壤氮、磷循环的影响}

土壤动物在养分循环, 尤其是氮、磷元素的循 环中具有重要作用(殷秀琴等, 2007)。马陆作为调落 物转换者, 通过取食凋落物影响土壤氮循环(Anderson et al, 1983; Fujimaki et al, 2010)。Hopki 和Read (1992)及Brogden等(2018)的研究发现, 马陆能增强 土壤的硝化作用。当其排泄的粪球中富含的 $\mathrm{NH}_{4}{ }^{+}$ 进入土壤后, 经硝化作用使土壤中 $\mathrm{NO}_{3}{ }^{-}$增多(Iwashima et al, 2011)。Makoto等(2014)研究表明, 当温 度升高时, 马陆增加了土壤中无机氮的含量。生存 在热带的Glyphiulus granulatus, 其种群密度增加能 使土壤中的氮含量增加(Silva et al, 2017)。Harpaphe haydeniana在取食调落物后, 排泄的粪球可以增加 调落物分解率和氮矿化, 并且影响沿海森林土壤中 微生物活动和多样性(Cárcamo et al, 2000)。造成以 上结果的原因包括: 首先, 马陆取食作用能够破碎 调落物, 促进氮的释放(Anderson et al, 1983); 其次, 马陆消化调落物时, 肠道微生物开始矿化氮, 导致 马陆粪球中 $\mathrm{NH}_{4}{ }^{+}$增加, 进而影响土壤中 $\mathrm{NH}_{4}{ }^{+}$含量 (Iwashima et al, 2011), 且粪球能激发土壤微生物的 活性，又进一步促进氮的矿化(Cárcamo et al, 2000)。 然而, Fujimaki等(2010)研究发现, 尽管马陆粪球中 总氮含量较高, 但在培养实验中增加Parafontaria laminata 个体的数量却导致土壤总氮的平均含量减 少。这可能是因为有机氮的固定增加, 调落物中的 氨基酸在马陆肠道中被同化, 使粪球中总氮含量减 少, 所以进入土壤中的总氮降低 (Rawlins et al, 2006)。值得注意的是, 马陆对土壤氮的影响具有一 定的时间滞后效应, 马陆活动过的土壤, 在随后几 周内, 氮的周转速率将发生显著变化(Anderson \& Ineson, 1984; Kaneko, 1999; Cárcamo et al, 2000)。

相比于土壤氮, 目前很少有研究关注马陆对磷 转化的影响(Silva et al, 2017)。Smit和Aarde (2001) 发现在马陆活动过的土壤中, 磷的有效性明显升
高。Silva等(2017)在巴西的研究发现当马陆Glyphiulus granulatus密度较高时, 其活动能提高土壤中 有效磷的含量。以上两项研究表明，马陆在土壤磷 循环转化方面有重要作用, 但是具体的影响机理还 有待进一步研究。

\section{马陆与其他生物之间的关系}

\section{1 马陆对微生物的调控作用}

马陆自身就是传播微生物的载体。在取食调落 物时, 马陆的口器会破坏调落物上的微生物群落 (Köiuhler \& Alberti, 1990)。在调落物被破碎后，其 表面积增大, 扩大了与微生物的接触面积, 加速了 调落物的分解(Kheirallah,1990)。凋落物经马陆肠道 过程转化为粪球。粪球主要由未完全消化的调落 物、矿物颗粒和微生物组成(Tajovský et al, 1992)。 马陆的肠道环境改变了调落物中微生物的特性, 使 粪球中微生物的特性与调落物中产生差异。

调落物在通过马陆肠道后, 微生物的数量表现 为细菌增加, 真菌减少。Anderson和Bignell (1980) 研究了微生物对于调落物转化成马陆粪球之后的 响应。将12只马陆Glomeris marginata培养24 h后, 计算了马陆粪球中细菌的数量, 结果显示调落物在 通过肠道后细菌数量增加了10-100倍。Maraun和 Schew (1996)的研究表明，真菌在通过 Glomeris marginata肠道时比细菌更彻底地被消化。Ambarish 和Sridhar (2016)发现, 粪球中的异养细菌、放线菌 和根瘤菌数量增多, 真菌数量下降。虽然在马陆肠 道内, 调落物中大部分真菌和多数细菌都会被杀死, 但剩余的细菌可以在后肠中以高的生长速率再繁 殖(Byzov et al, 1996, 1998b), 因而粪球中细菌数量 增加。粪球中微生物的特性会随粪球产生时间的推 移而发生变化, 食物来源和质量也可对粪球中的微 生物特性有较大影响(Joly et al, 2015)。

\section{2 马陆与蚯蚓的互作关系}

蚯蚓是常见的大型土壤无脊椎动物, 通过取 食、消化、排泄、分泌及掘穴等活动在生态系统中 发挥其功能, 并与蚂蚁、白蚁等一起被称为“生态系 统工程师” (Holdsworth et al, 2007)。在同一生境中, 马陆和蝶蚓既可能存在正相互作用, 又可能出现负 相互作用, 这主要取决于生境中的物种类型。

在欧洲山毛榉(Fagus longipetiolata)林中, 蚳蚓 Octolasion lacteum取食马陆Glomeris marginata的粪 
球, 并将调落物与矿物土壤混合(Scheu, 1987; Scheu \& Wolters, 1991)。Bonkowski 等(1998) 推测蚯蚓 Octolasion lacteum与马陆Glomeris marginata是森林 中调落物分解和腐殖质形成的重要因素, 二者的联 合对于山毛榉林土壤的形成和维持不可或缺。另一 项研究发现, 将蚯蚓 Amynthas agrestis 和马陆 Sigmoria ainsliei放置在一起或者隔离开的实验表明, 当没有虾蚓时，马陆存活状态较好; 当没有马陆时, 蚯蚓的繁殖能力会提高; 若这两种土壤动物共同利 用有限的资源, 二者对资源产生竞争, 蝶蚛可能会 分泌粘液杀死马陆(Snyder et al, 2013)。

\section{未来展望}

马陆在生态系统中扮演着重要角色, 是整个生 态系统中不可缺少的一员。然而, 当前对大型土壤 动物的研究虽多, 但与马陆相关的研究并不多见 (廖崇惠等, 1992; 张雪萍等, 2001)。由于马陆数量 庞大, 种类繁多, 对调落物的分解转化具有重要作 用, 排泄的粪球是土壤食物网中重要的环节, 影响 生态系统中的养分循环, 因而必须引起重视 (Scheu \& Wolters, 1991; Shelley, 2003)。结合当前土 壤生态学和生态系统的热点问题和发展趋势, 未来 对马陆的研究应考虑以下几个方向:

\section{1 马陆的分类鉴定}

马陆种类繁多, 数量巨大, 目前所记载的数量 仅占全球种类的 $15 \%$, 大多数马陆种类在分类学上 仍是未知(Naveed et al, 2014; Oeyen \& Wesener, 2018)。马陆在森林生态系统中的多样性、分布、鉴 定和作用对很多研究者来说是一个瓶颈(Shelley \& Shear, 2005; Marek \& Bond, 2006; Choudhari et al, 2014)。物种实际数量与估计数量之间的差异使我们 对马陆的了解十分有限(Brewer et al, 2012)。除了有 关的分类学知识不够充分之外, 在鉴定方法和技术 层面依然需要提升。邵元虎等(2015)研究表明, 分子 技术可能对土壤动物多样性的研究起到巨大的推 动作用。可以将分子生物学鉴定技术与马陆传统分 类和形态鉴定技术相结合，提高对马陆物种鉴定的 准确性和效率。

\section{2 马陆的生态功能}

近30年来, 学者们对土壤动物生态功能的研究 日益加强(贺纪正等, 2015)。根据 其他土壤动物类群 的研究以及当前突出的问题, 以下领域可能成为马
陆生态功能研究的热点:

(1)马陆肠道对所摄取调落物的影响。马陆肠道 会选择性地降解有机物、同化营养物质。Rawlins 等(2006)利用湿化学方法和气相色谱法研究了调落 物在经马陆肠道转化为粪球后生物分子组成的变 化。结果表明，马陆粪球中甾醇、三酸甘油酯、可 溶解的碳水化合物和蛋白质的浓度均降低。

Ambarish和Sridhar (2016)发现，马陆粪球中粗蛋 白、有机碳、总氮和总酚的含量比凋落物中的含量 低。在分子水平上关于马陆肠道消化对调落物的化 学效应即马陆肠道如何对调落物进行选择性化学 转化,调落物的化学性质如何变化, 其中的机理需 要深入研究。

(2)马陆如何调控土壤中养分元素的循环。当前 的相关研究中, 对磷和钾关注较少, 其他中量和微 量元素更是很少涉及(贺纪正等, 2015)。因而将室内 实验与野外控制样地相结合，研究马陆如何通过取 食代谢活动促进养分循环，对土壤中养分元素在短 期和长期内的影响是否具有一致性，如何调控中量 和微量元素, 对于土壤生态学的发展也具重要意义。

(3)马陆对土壤结构的影响。土壤均衡的孔隙和 团聚结构组合可能是其他土壤生态功能正常发挥 的基础。土壤动物的生物扰动可直接形成土壤生物 孔隙结构, 其排泄物和分泌物对土壤结构的形成具 有重要作用。此外, 土壤动物的活动影响植物根系 生长、有机物分解及微生物活性，这会直接改变土 壤结构的形成过程(贺纪正等, 2015)。已有研究表明, 马陆使土壤中大颗粒团聚体含量增加(Makoto et al, 2014; Silva et al, 2017)。然而，马陆对于团聚体的影 响是否仅限于特定大小、是否与肠道活动或调落物 材质有关，仍未有定论(Silva et al, 2017)。此外，当 前依然缺乏在较大时空尺度上土壤动物对土壤侵 蚀等过程的关注，因而对于马陆的研究可以向这些 方向扩展。

(4)马陆与其他生物的互作。研究表明, 土壤动 物与土壤微生物的关系并非单向，土壤动物的取食 可干扰微生物，而土壤微生物也能对土壤动物主动 进行防御(Jousset et al, 2008)。另一方面，土壤动物 与植物生长过程的关系也是个热点问题(贺纪正等, 2015)。未来应更加注重马陆与其他生物的互作、马 陆在土壤食物网内的营养级及其上行效应和下行 效应的研究。如马陆在取食调落物时, 调落物中微 
生物是否也会主动防御, 这能否影响马陆的取食率 和同化效率? 马陆通过营养级间的相互作用如何 调节植被生长? 即马陆在取食调落物时, 通过破碎 调落物而释放氮, 这个过程是否影响植物的生长及 初级生产? 此外, 应关注马陆与哪些土壤动物在生 态功能上具有相似性。当马陆受到自然或者人为因 素的干扰时, 这些功能相似的土壤动物类群是否可 以充分发挥其生态功能, 从而维护生态系统的协调 稳定?

(5)马陆与生态系统服务。物种是功能性状的集 合, 物种功能性状通过影响生态系统的属性和过程 等影响生态系统服务, 尤其是对生物地球化学过程 造成影响(范玉龙等, 2016)。鉴于马陆在生态系统中 的重要作用, 其对生态系统服务带来的影响应受到 更多的关注。

\section{3 马陆的生态结构与全球变化}

目前有关土壤生物响应和反馈全球变化的研 究还很贵乏(Allison \& Treseder, 2010)。冊庸置疑的 是, 极端气候事件会对生态系统和生物多样性产生 强烈影响(邵元虎等, 2015; 韩会庆等, 2018)。近年 来, 大气氮沉降的问题越来越严重, 而我国有关土 壤动物对氮沉降响应的研究报道甚少 (荣海等, 2011), 有关氮沉降对马陆影响的研究也有限。在全 球变化背景下, 马陆的生存范围如何变化,其种群 密度是否改变,生理特征是否受到影响以及是否存 在其他潜在的效应，我们不得而知。

\section{参考文献}

Adis J (2002) Taxonomical classification and biodiversity. ACM Transactions on Graphics, 33, 1-10.

Allison SD, Treseder KK (2010) Warming and drying suppress microbial activity and carbon cycling in boreal forest soils. Global Change Biology, 14, 2898-2909.

Ambarish CN, Sridhar KR (2016) Chemical and microbial characterization of feed and faeces of two giant pill-millipedes from forests in the western Ghats of India. Pedosphere, 26, 861-871.

Anderson JM, Bignell DE (1980) Bacteria in the food, gut contents and faeces of the litter-feeding millipede Glomeris marginata (Villers). Soil Biology \& Biochemistry, 12, 251-254.

Anderson JM, Ineson P (1984) Interactions Between Microorganisms and Soil Invertebrates in Nutrient Flux Pathways of Forest Ecosystems. Cambridge University Press, Cambridge.

Anderson JM, Ineson P, Huish SA (1983) Nitrogen and cation mobilization by soil fauna feeding on leaf litter and soil organic matter from deciduous woodlands. Soil Biology \& Biochemistry, 15, 463-467.

Ashwini KM, Sridhar KR (2005) Leaf litter preference and conversion by a saprophagous tropical pill millipede, Arthrosphaera magna, Attems. Pedobiologia, 49, 307-316.

Bailey PT (1989) Millipede parasitoid Pelidnoptera nigripennis (F.) (Diptera: Sciomyzidae) for the biological control of the millipede Ommatoiulus moreleti (Lucas) (Diplopoda: Julida: Julidae) in Australia. Bulletin of Entomological Research, 7, 381-391.

Barlow CA (1957) A factorial analysis of distribution in three species of Diplopods. Tijdschrift Voor Entomologie, 100, 349-426.

Bardgett RD, Wardle DA (2010) Aboveground-belowground Linkages: Biotic Interactions, Ecosystem Processes, and Global Change. Oxford University Press, Oxford.

Bonkowski M, Scheu S, Schaefer M (1998) Interactions of earthworms (Octolasion lacteum), millipedes (Glomeris marginata) and plants (Hordelymus europaeus) in a beechwood on a basalt hill: Implications for litter decomposition and soil formation. Applied Soil Ecology, 9, 161-166.

Brewer MS, Spruill CL, Rao NS, Bond JE (2012) Phylogenetics of the millipede genus Brachycybe Wood, 1864 (Diplopoda: Platydesmida: Andrognathidae): Patterns of deep evolutionary history and recent speciation. Molecular Phylogenetics \& Evolution, 64, 232-242.

Brogden MC, Cortes C, Vandevoort AR, Snyder BA (2018) Soil nitrification analysis and millipede contribution. Georgia Journal of Science, 76, 117.

Buch AC, Sisinno CLS, Correia MEF, Silva-Filho EV (2018) Food preference and ecotoxicological tests with millipedes in litter contaminated with mercury. Science of the Total Environment, 633, 1173-1182.

Byzov BA, Tretyakova EB, Zvyagintsev DG, Claus H, Filip Z (1996) Effects of soil invertebrates on the survival of some genetically engineered bacteria in leaf litter and soil. Biology and Fertility of Soils, 23, 221-228.

Byzov BA, Kurakov AV, Tretyakova EB, Thanh VN, Luu ND, Rabinovich YM (1998a) Principles of the digestion of microorganisms in the gut of soil millipedes: Specificity and possible mechanisms. Applied Soil Ecology, 9, 145-151.

Byzov BA, Thanh VN, Babeva IP, Tretyakova EB, Dyvak IA, Yam R (1998b) Killing and hydrolytic activities of the gut fluid of the millipede Pachyiulus flavipes C. L. Koch on yeast cells. Soil Biology \& Biochemistry, 30, 1137-1145.

Cárcamo HA, Abe TA, Prescott CE, Holl FB, Chanway CP (2000) Influence of millipedes on litter decomposition, $\mathrm{N}$ mineralization, and microbial communities in a coastal forest in British Columbia, Canada. Canadian Journal of Forest Research, 30, 817-826.

Choudhari CR, Dumbare YK, Theurkar SV (2014) Diversity of millipedes along the Northern Western Ghats, Rajgurunagar 
(MS), India (Arthropod: Diplopod). Journal of Entomology and Zoology Studies, 2, 254-257.

Coleman DC, Crossley DA (1996) Fundamentals of Soil Ecology. Academic Press, San Diego, CA.

Crawford CS (1975) Food, ingestion rates, and assimilation in the desert millipede Orthoporus ornatus (Girard) (Diplopoda). Oecologia, 20, 231-236.

David JF, Gillon D (2002) Annual feeding rate of the millipede Glomeris marginata, on holm oak (Quercus ilex) leaf litter under Mediterranean conditions. Pedobiologia, 46, 42-52.

Devi DS, Prabhoo NR (1990) Studies on food and feeding habits, food preference and feeding mechanism in the millipede Jonespeltis splendidus Verhoeff in captivity. Uttar Pradesh Journal Zoology, 10, 48-56.

Drift JVD (1975) Progress in Soil Zoology. Springer, the Netherlands.

Edwards CA, Hendrix PF (2004) Earthworm Ecology, 2nd edn. St. Lucie Press, Boca Raton.

Fan YL, Hu N, Ding SY, Liang GF, Lu XL (2016) Progress in terrestrial ecosystem services and biodiversity. Acta Ecologica Sinica, 36, 4583-4593. (in Chinese with English abstract) [范玉龙, 胡楠, 丁圣彦, 梁国付, 卢训令 (2016) 陆地生态系统服务与生物多样性研究进展. 生态学报, 36, 4583-4593.]

Frouz J, Špaldoňová A, Fričová K, Bartuška M (2014) The effect of earthworms (Lumbricus rubellus) and simulated tillage on soil organic carbon in a long-term microcosm experiment. Soil Biology \& Biochemistry, 78, 58-64.

Fujimaki R, Sato Y, Okai N, Kaneko N (2010) The train millipede (Parafontaria laminata) mediates soil aggregation and $\mathrm{N}$ dynamics in a Japanese larch forest. Geogerma, 159, 216-220.

Golovatch SI, Kime RD (2009) Millipede (Diplopoda) distributions: A review. Soil Organisms, 81, 337-346.

Han HQ, Zhang JY, Ma G, Zhang XD, Bai YM (2018) Advances on impact of climate change on ecosystem services. Journal of Nanjing Forestry University (Natural Science Edition), 42, 184-190. (in Chinese with English abstract) [韩会庆, 张娇艳, 马庚, 张新鼎, 白玉梅 (2018) 气候变 化对生态系统服务影响的研究进展. 南京林业大学学报 (自然科学版), 42, 184-190.]

Hashimoto M, Kaneko N, Ito MT, Toyota A (2004) Exploitation of litter and soil by the train millipede Parafontaria laminata (Diplopoda: Xystodesmidae) in larch plantation forests in Japan. Pedobiologia, 48, 71-81.

He JZ, Lu YH, Fu BJ (2015) Frontiers of Soil Biology. Science Press, Beijing. (in Chinese) [贺纪正, 陆雅海, 傅伯杰 (2015) 土壤生物学前沿. 科学出版社, 北京.]

Holdsworth AR, Frelich LE, Reich PB (2007) Regional extent of an ecosystem engineer: Earthworm invasion in northern hardwood forests. Ecological Applications, 17, 1666-1677.

Hopkin SP, Read HJ (1992) The Biology of Millipedes. Quarterly Review of Biology. Oxford University Press, Oxford.
Iwashima N, Kaneko N, Sato K, Wakatsuki T, Masunaga, T (2011) Comparison of the faecal chemical properties of two geophagous millipede species Parafontaria laminata and Parafontaria tonominea (Xystodemidae) considering effects of habitat density and type of food. Edaphologia, 88, 43-53. (in Japanese with English summary)

Joly FX, Coulis M, Gérard A (2015) Litter-type specific microbial responses to the transformation of leaf litter into millipede feces. Soil Biology \& Biochemistry, 86, 17-23.

Jousset A, Scheu S, Bonkowski M (2008) Secondary metabolite production facilitates establishment of rhizobacteria by reducing both protozoan predation and the competitive effects of indigenous bacteria. Functional Ecology, 22, 714-719.

Kaneko N (1999) Effect of millipede Parafontaria tonominea Attems (Diplopoda: Xystodesmidae) adults on soil biological activities: A microcosm experiment. Ecological Research, 14, 271-279.

Kheirallah AM (1990) Fragmentation of leaf litter by a natural population of the millipede Julus scandinavius (Latzel 1884). Biology and Fertility of Soils, 10, 202-206.

Köiuhler HR, Alberti G (1990) Morphology of the mandibles in the millipedes (Diplopoda, Arthropoda). Zoologica Scripta, 19, 195-202.

Lavelle P, Spain AV (2001) Soil Ecology. Kluwer Academic Publishers, Dordrecht.

Liao CH, Chen MQ, Chen JH (1992) Population ecology of two species of terrestrial isopods and their role in litter decomposition. Acta Zoologica Sinica, 38, 23-29. (in Chinese with English abstract) [廖崇惠, 陈茂乾, 陈锦华 (1992) 两种陆栖等足类的种群及其分解落叶的作用. 动物学报, 38, 23-30.]

Lyford WH (1943) Palatability of freshly fallen leaves of forest trees to millipedes. Ecology, 24, 252-261.

Makoto K, Arai M, Kaneko N (2014) Change the menu? Species-dependent feeding responses of millipedes to climate warming and the consequences for plant-soil nitrogen dynamics. Soil Biology \& Biochemistry, 72, 19-25.

Maraun M, Scheu S (1996) Changes in microbial biomass, respiration and nutrient status of beech (Fagus sylvatica) leaf litter processed by millipedes (Glomeris marginata). Oecologia, 107, 131-140.

Marek PE, Bond JE (2006) Phylogenetic systematics of the colorful, cyanide-producing millipedes of appalachia (Polydesmida, Xystodesmidae, Apheloriini) using a total evidence Bayesian Approach. Molecular Phylogenetics \& Evolution, 41, 704-729.

Naveed M, Moldrup P, Arthur E, Holmstrup M , Nicolaisen M, Tuller M, Herath L, Hamamoto S, Kawamoto K, Komatsu T, Vogeland H, Jonge L (2014) Simultaneous loss of soil biodiversity and functions along a copper contamination gradient: When soil goes to sleep. Soil Science Society of America Journal, 78, 1239-1250. 
Oeyen JP, Wesener T (2018) A first phylogenetic analysis of the pill millipedes of the order glomerida, with a special assessment of mandible characters (Myriapoda, Diplopoda, Pentazonia). Arthropod Structure \& Development, 47, 214-228.

Pobozsny M, Gonzales Oliver R, Rodriguez ME (1992) The role of Trigonoiulus lumbricinus Gerst. (Diplopoda) in the decomposition of leaf litter in some plant communities of Cuba. Opuscula Zoologica Budapest, 25, 89-93.

Rawlins AJ, Bull ID, Poirier N, Ineson P, Evershed RP (2006) The biochemical transformation of oak (Quercus robur) leaf litter consumed by the pill millipede (Glomeris marginata). Soil Biology \& Biochemistry, 38, 1063-1076.

Reichle DE, Shanks MH, Crossley DA (1969) Calcium, potassium, and sodium content of forest floor arthropods. Annals of the Entomological Society of America, 62, 57-62.

Rong H, Fan HL, Li Q, Li J, Hong W, Wu CZ (2011) Effects of simulated nitrogen deposition on soil macrofauna in agroecosystem. Journal of North East Forestry University, 39(1), 85-88. (in Chinese with English abstract) [荣海, 范 海兰, 李茜, 李键, 洪伟, 吴承祯 (2011) 模拟氮沉降对 农田大型土壤动物的影响. 东北林业大学学报, 39(1), 85-88.]

Sakwa WN (1974) A consideration of the chemical basis of food preference in millipedes. Symposium of Zoological Society of London, 32, 329-346.

Scheu S, Wolters V (1991) Influence of fragmentation and bioturbation on the decomposition of ${ }^{14} \mathrm{C}$-labelled beech leaf litter. Soil Biology \& Biochemistry, 23, 1029-1034.

Scheu S (1987) The role of substrate feeding earthworms (Lumbricidae) for bioturbation in a beechwood soil. Oecologia, 72, 192-196.

Shao YH, Zhang WX, Liu SJ, Wang XL, Fu SL (2015) Diversity and function of soil fauna. Acta Ecologica Sinica, 35, 6614-6625. (in Chinese with English abstract) [邵元虎, 张 卫信, 刘胜杰, 王晓丽, 傅声雷 (2015) 土壤动物多样性 及其生态功能. 生态学报, 35, 6614-6625.]

Shelley RM (2003) Taxonomy of extant Diplopoda (Millipeds) in the modern era: Perspectives for future advancements and observations on the global Diplopod community (Arthropoda: Diplopoda). Zootaxa, 1668, 343-362.

Shelley RM, Shear WA (2005) A new milliped of the genus Stenozonium Shelley 1998 from Washington State, U.S.A.: First record of the genus and family from North of the Columbia River (Polyzoniida: Polyzoniidae). Zootaxa, 1017, 25-32.

Sierwald P, Bond JE (2007) Current status of the Myriapod class Diplopoda (Millipedes): Taxonomic diversity and phylogeny. Annual Review of Entomology, 52, 401-420.

Silva VMD, Antoniolli ZI, Jacques RJS, Ott R, Andrade FV, Passos RR (2017) Influence of the tropical millipede,
Glyphiulus granulatus (Gervais, 1847), on aggregation, enzymatic activity, and phosphorus fractions in the soil. Geoderma, 289, 135-141.

Smit AM, Van Aarde RJ (2001) The influence of millipedes on selected soil elements: A microcosm study on three species occurring on coastal sand dunes. Functional Ecology, 15, 51-59.

Snyder BA, Callaham MAJ, Lowe CN, Hendrix PF (2013) Earthworm invasion in North America: Food resource competition affects native millipede survival and invasive earthworm reproduction. Soil Biology \& Biochemistry, 57, 212-216.

Suzuki Y, Grayston SJ, Prescott CE (2013) Effects of leaf litter consumption by millipedes (Harpaphe haydeniana) on subsequent decomposition depends on litter type. Soil Biology \& Biochemistry, 57, 116-123.

Tajovský K, Santruckova H, Hanel L, Balik V, Lukesova A (1992) Decomposition of faecal pellets of the millipede Glomeris hexasticha (Diplopoda) in forest soil. Pedobiologia, 36, 146-158.

Toyota A, Kaneko N, Ito MT (2006) Soil ecosystem engineering by the train millipede Parafontaria laminata, in a Japanese larch forest. Soil Biology \& Biochemistry, 38, 1840-1850.

Wang MN, Lu XL, Ding SY, Ren JY, Bian ZQ, Xu Z (2017) Pollinator diversity in different habitats of the agricultural landscape in the middle and lower reaches of the Yellow River based on the three-color pan trap method. Acta Ecologica Sinica, 37, 148-155.

Wolters V (2000) Invertebrate control of soil organic matter stability. Biology and Fertility of Soils, 31, 1-19.

Wooten RC, Crawford CS (1975) Food, ingestion rates, and assimilation in the desert millipede Orthoporus ornatus (Girard) (Diplopoda). Oecologia, 20, 231-236.

Yin XQ, Song B, Qiu LL (2007) Dynamic characteristic of N, $\mathrm{P}, \mathrm{K}$ in the litter-soil fauna-soil system of mixed Pinus koraiensis and broad-leaved forest. Acta Ecologica Sinica, 27, 128-134. (in Chinese with English abstract) [殷秀琴, 宋博, 邱丽丽 (2007) 红松阔叶混交林调落物-土壤动物土壤系统中 $N 、 P 、 K$ 的动态特征. 生态学报, 27, 128-134.]

Zhang WX, Chen DM, Zhao CC (2007) Functions of earthworm in ecosystem. Biodiversity Science, 15, 142-153. (in Chinese with English abstract) [张卫信, 陈迪马, 赵灿灿 (2007) 蚳蚓在生态系统中的作用. 生物多样性, 15, 142-153.]

Zhang XP, Li CY, Zhang SC (2001) Study of the function of millipedes in substance decomposition. Acta Ecologica Sinica, 21, 75-79. (in Chinese with English abstract) [张雪 萍, 李春艳, 张思冲 (2001) 马陆在森林生态系统物质转 化中的功能研究. 生态学报, 21, 75-79.]

(责任编委: 吴纪华 责任编辑: 黄祥忠、周玉荣) 